University of Rhode Island

DigitalCommons@URI

The Rhode Island Current Conditions Index

Economics

$6-2016$

\title{
Rhode Island Current Conditions Index -- June 2016
}

Leonard Lardaro

University of Rhode Island, lardaro@uri.edu

Follow this and additional works at: https://digitalcommons.uri.edu/ricci

Part of the Econometrics Commons

Terms of Use

All rights reserved under copyright.

\section{Recommended Citation}

Lardaro, Leonard, "Rhode Island Current Conditions Index -- June 2016" (2016). The Rhode Island Current Conditions Index. Paper 150.

https://digitalcommons.uri.edu/ricci/150

This Article is brought to you for free and open access by the Economics at DigitalCommons@URI. It has been accepted for inclusion in The Rhode Island Current Conditions Index by an authorized administrator of DigitalCommons@URI.For more information, please contact digitalcommons-group@uri.edu. 


\section{CURRENT CONDITIONS}

\section{LEONARD LARDARO, URI}

\author{
Available Online: http:/ / www .llardaro.com/ current.htm \\ Blog: http:/ / rieconomy.blogspot.com \\ Twitter: @ladardo
}

VOL XXYHI
NUMBER 7
JUN 2016

employment and is a prerequisite to employment growth, fell by a hefty 3.7 percent in June, its fourth consecutive decline. Along with this, New Claims, a leading labor market indicator that reflects layoffs, rose $(+4.1 \%)$ in June, although it too had a difficult comp a year ago. Single-Unit Permits fell sharply $(-26.6 \%)$ following a rise of 17.7 percent a year ago. Its level, however, remained well below 1,000 annual units. Finally, US Consumer Sentiment fell by 6.3 percent in June, failing to beat a difficult 2015 comp, and sustaining its recent downtrend.

The sole improving leading indicator, Total Manufacturing Hours, a proxy for manufacturing output, rose slightly for only a second consecutive time, besting a fairly easy comp last June. Manufacturing employment rose by more than enough (proportionately) to offset the effect of a declining workweek.

Along with this deteriorating performance of several key cyclical indicators I have been highlighting of late, issues remained with most the remaining $\mathrm{CCl}$ indicators. Our state's Labor Force continued to decrease on a year-over-year basis. June's decrease of 0.5 percent was its twenty-fifth such decline. As a result, although its monthly performance was acceptable, Rhode Island's Unemployment Rate is still falling for the wrong reasons.

Retail Sales, fell by 0.6 percent in J une, its fourth decline in the past five months. The Manufacturing Wage rose again in J une, by 5.2 percent (back to fantasy land!!!). Private ServiceProducing Employment saw an an acceleration in its growth rate for June $(+1.1 \%)$, resuming its uptrend. Government Employment fell again $(-0.7 \%)$ in June, while Benefit Exhaustions, which reflects longer-term unemployment, fell by 30.5 percent, its best rate of improvement in quite a while.
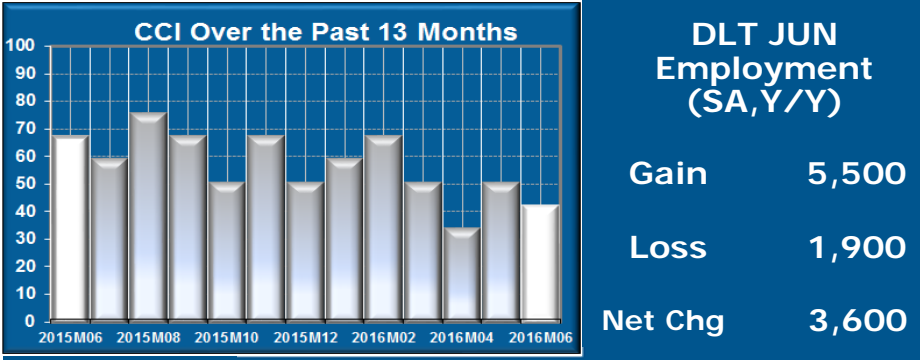

THE BOTTOM LINE Where all of this comes together is that monthly improvements, if sustained, eventually translate into yearly improvement. Unfortunately, the opposite is also true. The question now for Rhode Island is whether our monthly performance will improve or deteriorate for the remainder of this year. In other words, has our previous cyclical momentum disappeared? Right now we find ourselves stuck at or near neutral. As things nationally appear to be picking up, this might bode well for Rhode Island-hopefully!

Four of the five leading indicators contained in the $\mathrm{CCl}$ failed to improve in June, and all of them had difficult comps from a year ago. Employment Service Jobs, which includes temporary
The second quarter was not a good one for Rhode Island. Once again our state's economy remained stuck in neutral, something that has now occurred for four consecutive months. Not only have we failed to exceed year-earlier $\mathrm{CCl}$ values for all but one month this year, key cyclical indicators as a group continue to display a very concerning pattern. While there are and have been some bright spots throughout this year, especially June's payroll employment, it is not clear at this point whether we will ultimately be able to sustain more broadly based momentum. It appears that the national economy has begun to improve. That single factor will largely determine our fate.

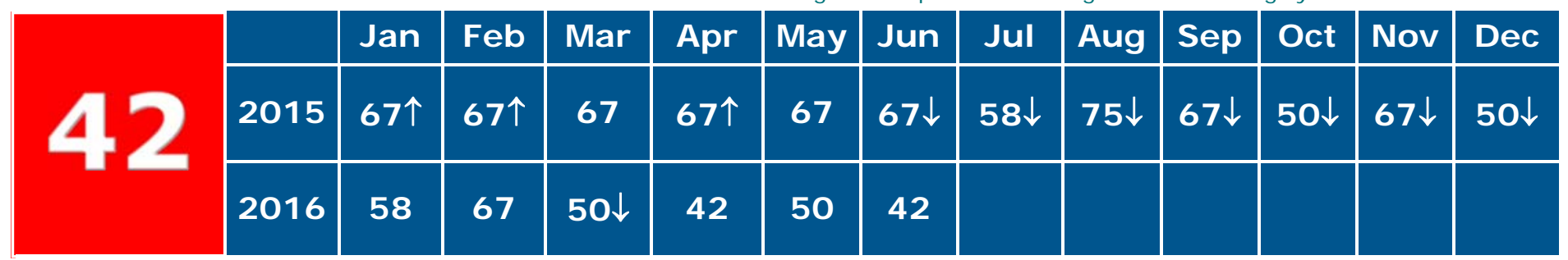

